\title{
THE FIFTH AMENDMENT AND THE FEDERAL GAMBLING TAX
}

\author{
NO SINGLE CLAUSE in our Federal Constitution has, in recent \\ years, provoked more controversy than the fifth amendment's \\ privilege against self-incrimination; ${ }^{1}$ nor could any constitutional con-
} troversy better reflect the tug of the public interest against private rights. Society's interest in having a full disclosure of all criminal activity must be balanced against the right of the individual to be free from unrestrained government inquisition. There will never be any unanimous agreement on how this balance is to be struck, ${ }^{2}$ but the weight of public opinion is bound to find expression at various times in concrete legislation and, to a lesser extent, in judicial decision. ${ }^{3}$

A partial appraisal of how our society as a whole presently values the fifth amendment privilege can perhaps be made by an examination of the constitutional implications of the recently enacted Federal Gam-

\footnotetext{
1 "No person . . . shall be compelled in any criminal case to be a witness against himself." U.S. ConsT. amend. V.

${ }^{2} \mathrm{Mr}$. Chief Justice Taft thought that if the Constitution were to be rewritten today, this privilege would be omitted. Grant, Self-Incrimination in the Modern American Law, 5 TEMP. L.Q. 368 (193I). Political scientist Edward S. Corwin believes that the self-incrimination privilege unduly hampers society's war against crime. CoRwIN, The Supreme Court's Construction of the Self-Incrimination Clause, in 2 SELECTEd Essays on Constitutional Law 1433 (Maggs ed. 1938). For a contrary view, see Mr. Justice Black's dissent in Rogers v. United States, 340 U.S. $367,375-76$ (1951). Likewise, Dean Griswold has written, "I would like to venture the suggestion that the privilege against self-incrimination is one of the great landmarks in man's struggle to make himself civilized. ... If a man has done wrong, he should be punished. But the evidence against him should be produced, and evaluated by a proper court in a fair trial. Neither torture nor an oath nor the threat of punishment such as imprisonment for contempt should be used to compel him to provide the evidence to accuse or to convict himself." Griswold, The Fifi h AMendment Today 7-8 (1955).

${ }^{3}$ This is not to imply that constitutional civil rights are relative. Perhaps the yicld of the judiciary to the volatile "temper of our times" can be theoretically reconciled with the stability of constitutional civil liberties by saying that changing social conditions produce variables on the surface of fundamental rights. Nevertheless, the fact remains that even judges react to public opinion. However, Mr. Justice Bradley, speaking of self-incrimination and search and seizure in Boyd $v$. United States, I I 6 U.S. 616, 635 (I 886), warned against these subtic encroachments on constitutional guarantees: "[I]11cgitimate and unconstitutional practices get their first footing . . . by silent approaches and slight deviations from legal modes of procedure. This can only be obvinted by adhering to the rule that constitutional provisions for the security of person and property should be liberally construed."
} 
bling Tax. 4 This statute requires the annual purchase of a fifty dollar stamp by all professional gamblers, ${ }^{5}$ and imposes a ten per cent excise tax upon all wagers placed with such gamblers. ${ }^{6}$ In addition, the "taxpayer" must register with the District Director of Internal Revenue and reveal his places of business and the names and addresses of all persons who accept wagers for him. ${ }^{7}$ Furthermore, the Code directs each internal revenue office to make these tax lists available to state prosecuting officers. ${ }^{8}$

It is apparent that the practical effect of these provisions is to force the gambler to choose between openly exposing himself to state prosecutions for gambling ${ }^{9}$ and risking federal prosecution for tax avoid-

\footnotetext{
- The general provisions of this tax may be found in INT. REv. CODE OF I954, $\$ \S 440 \mathrm{r-23}$. Unfortunately, all the pertinent provisions are not collected in one place, but are spread throughout the Code. As cited in succeeding footnotes, $\$ \$ 6 \times 07,6653$, 6806 (c) $, 7201,7203,7262$ and 7273 (b) must be included to comprehend the terms of the tax fully. For a discussion of this statute, see Coons, The Federal Gambling Tax and the Constitution, 43 J. CRIM. L., C. \& P.S. 637 (1953).

${ }^{5}$ INT. REv. CODE OF I954, $\$ 44 \mathrm{Ir}$. "There shall be imposed a special tax of $\$ 50$ per year to be paid by each person who is liable for tax under section $440 \mathrm{r}$ or who is engaged in receiving wagers for or on behalf of any person so liable."

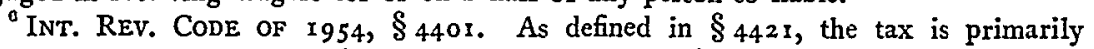
directed toward bookmakers (off-track race horse betting), operators of lotteries, numbers, policy, and pools. It does not apply to poker, dice, roulette or other similar games. Also specifically exempted by $\S 4402$ (I) are wagers placed with a parimutuel system (on-track race horse betting) licensed by a state. If this statute is truly a tax measure rather than an attempted exercise of federal police power, it is surprising that Congress should by-pass such a lucrative source of revenue.

'INT. Rev. CODE OF r954, \$ 44 r2.

${ }^{8}$ INT. REv. CoDE of 1954, §6107. This list of stamp purchasers is often published by the press. For example, see Durham [North Carolina] Morning Herald, Oct. 7 , 1955, p. x, col. 3. Thus, the pressure of public opinion may force recalcitrant prosecutors to issue indictments to those named taxpayers, though there is no other substantiating evidence. That such a contingency would occur was raised in congressional debate concerning this bill. See United States 0 . Kahriger, 345 U.S. 22,27 n. 3 (1952). State prosecutors are additionally aided by $\S 6806$ (c), which requires each stamp purchaser to post the stamp in a conspicuous spot in his principal place of business; and if he has none, to carry the stamp on his person and show it on request to any Treasury official. A $\$ 50$ fine is imposed for negligent failure to comply with this section, and for willful neglect or failure the fine is doubled. $I d . \S 7273(\mathrm{~b})$.

${ }^{\circ}$ With the exception of Tennessee, which classifies it as a felony, TENN. CODE ANN. $\S$ s1290 (Williams 1934), gambling is a misdemeanor in all states but Nevada, where every form of gambling has been legalized. The state penalties are generally not as severe as those prescribed in the federal statute for avoiding the gambling tax. For example, New Jersey penalizes a bookmaker with a fine of $\$ 1000-\$ 5000$ and /or one to five years in jail, N.J. STAT. ANN. tit. 2A, \$ II2-3 (1953). Pennsylvania specifies a maximum fine of $\$ 500$ and /or one year in jail, PA. STAT. ANN. tit. $18, \S 4601$ (1945);
} 
ance. ${ }^{10}$ Despite this inherent incriminatory element, two recent Supreme Court cases ${ }^{11}$ have held the tax constitutional. Though the issue has thus, at least for the present, been set at rest in the federal courts, this does not foreclose an examination of the present vitality of our fifth amendment privilege as reflected by the judicial acceptance of a statute, the very design of which is to compel testimony in aid of state law enforcement. $^{12}$

and North Carolina a maximum fine of $\$ 2000$ and/or six months in prison, N.C. GEN. STAT. § I4-29o (1953).

${ }^{10}$ One who willfully refuses to pay this gambling tax could face a fine in excess of $\$ 15,000$ and five years in prison. $\$ 7262$ of the INT. REv. CODE OF 1954 imposes a fine of $\$ 1000-\$ 5000$ for failure to buy the stamp or pay the required ten per cent excise. Section 6653 prescribes an additional penalty of fifty per cent of the underpayment of the tax for willful failure to pay. $\$ 720 \mathrm{x}$ declares in addition to the above penalties that one willfully attempting to evade the payment of this tax shall, on conviction, be declared guilty of a felony and receive a maximum fine of $\$ 10,000$ and/or imprisonment for not more than five years. Finally, $\$ 7203$ punishes failure to file a return, or to keep the required records, by a maximum fine of $\$ 10,000$ and/or imprisonment for one year.

${ }^{11}$ United States v. Lewis, 348 U.S. 419 (1955), and United States v. Kahriger, 345 U.S. 22 (1952). Notes, 3 I CHI-KeNT L. REv. 359 (1953); 4 I Geo. L.J. 562 (1953); 67 HARv. L. REv. 164 (1953); 52 Mrch. L. Rev. I 50 (1953).

${ }_{12}$ Perhaps Congress felt that the federal power to regulate gambling activities directly is too narrow, and that the states themselves are unable to handle the problem adequately because of its national scope. Congress has exhausted the federal police power in this area: 64 STAT. x134-35 (x951), 15 U.S.C. $\$ \$ \times 17 x-77$ (1952) (interstate transportation of gambling devices); 63 STAT. 92 (1949), 18 U.S.C. $\$ \S$ x08 1-83 (x952) (gambling on ships or airplanes owned by American citizens, or of American registry, or in areas of federal jurisdiction); 37 STAT. 514 (1934), 48 U.S.C. $\$ 77$ (1946) (lotteries in Alaska); 31 STAT. 150 ( 1900 ), 48 U.S.C. $\$ 562$ (x946) (lotteries in Hawaii); 62 STAT. 762, 763 (1948), 64 STAT. 45 I (1950), 65 STAT. 721 (1951), 18 U.S.C. $\S \S 1301-05$ (1952) (importing lottery material); INT. REv. CODE OF 1954, $\$ 5723$ (b) (lottery material in packaged tobacco, cigars or cigarettes); 46 STAT. 688 (1930), 19 U.S.C. § 1305 (1946); and 26 STAT. 466 (1890), 39 U.S.C. $\$ \$ 259,732$ (1946) (supplementing the lottery sections). But by designing the present statute as a tax measure, an area where federal power is plenary, Congress was able to place a powerful deterrent on conduct punishable only by the states in the exercise of their police power.

The Senate Finance Committee attempted to emphasize the taxing feature of the statute by estimating the revenue from this tax at four hundred million dollars a year. Senate Committee on Finance, Report to Accompany H.R. 4473, 82d Cong., xst Sess. (195I). Apparently the Budget Bureau took the Senate at their word, as their fiscal estimate for 1953 was two hundred million dollars, Budget of the U.S. for 1953 Fiscal Year x 162 . Actual collections of the tax have never amounted to over $2.5 \%$ of the Senate's estimate. In 1952, five million was collected; in 1953 , ten million; and in 1954, nine million. Budget of the U.S. for the Fiscal Years Ending June 30, 1954 p. $1095 ; 1955 \mathrm{p} .1 \times 15 ; \times 956 \mathrm{p}$. 1150 . The ratio of excise to stamp collections has been about ten to one. Ann. Rep. of the Comm. of Int. Rev. for the Fiscal Year Ended June 30, 1953, pp. 92-93 (1954). The explanation would seem to be either that the 
The treatment of the problem will be divided into two sections. First, in what way do the provisions of the tax compel self-incrimination? And second, what protection does the fifth amendment offer against such incrimination?

\section{How the Tax Incriminates}

The fifth amendment secures the privilege of refusing to testify both as to those matters which will directly incriminate, and as to those which may serve as a link in a "chain of evidence" culminating in conviction. ${ }^{13}$ In United States v. Kahriger [6:3], ${ }^{14}$ and United States v. Lewis

Senate grossly miscalculated gambling activity in our nation, or that it attempted to cloak the penalty nature of the tax. The latter seems more probable.

${ }^{13}$ The "chain of evidence" rule was first expressed in Counselman 0 . Hitchcock, r40 U.S. 547,564 ( 1892 ). Judge Learned Hand in United States 0 . Weisman, $x \times 1$ F.2d 260, 262 (2d Cir. 1940), said, "All crimes are composed of definite elements, and nobody supposes that the privilege is confined to answers which directly admit one of these; it covers also such as logically, though mediately, lead to any of them; such as are rungs of the rational ladder by which they may be reached." See also Hoffman v. United States, 34I U.S. 479 (1951).

${ }^{13} 345$ U.S. 22 ( 1952 ). The case originated in the district court for the eastern district of Pennsylvania. Defendant was willing to pay the tax but refused to fill out the registration form, claiming protection of the fifth amendment. The court declared the law unconstitutional as a usurpation of the state police power under the guise of a taxing act, quoting extensively from United States 0. Constantine, 296 U.S. 287 (I935). This ruling made unnecessary any mention of the self-incrimination argument. United States v. Kahriger, 105 F. Supp. 322 (E.D. Pa. 1952). During the period of the Kalriger litigation seven other district courts upheld the constitutionality of the tax; but little was said about the question of possible incrimination. The opinions merely held that it was a valid taxing measure, not a penalty. Both United States . Nadler, ro5 F. Supp. 9 18 (N.D. Cal. 1952), and United States v. Robinson, ro7 F. Supp. 38 (E.D. Mich. 1952), said the tax would be an unconstitutional penalty were it not for legalized gambling in Nevada. United States v. Smith, ro6 F. Supp. 9 (S.D. Cal. 1952), announced generally that the power of Congress in the field of taxation is supreme, even though it may affect purely local activities. Combs o. Snyder, ror F. Supp. 53I (D.D.C. 195I), took the position that where defendant had applied for an injunction against the tax on the claim of self-incrimination, the constitutional question would not be discussed; and the petition was dismissed because defendant had "dirty hands," since he was seeking the court's protection of a criminal business. The court in United States $v$. Forrester, xo5 F. Supp. ${ }_{3} 6,1_{3} 8$ (N.D. Ga. 1952), agreed that the statute incriminated, but upheld its constitutionality as follows: "The statute complained of is a federal statute, compliance with which will tend to incriminate one under state laws, but not under federal laws. Consequently, the statute does not violate the constitutional safeguards against self-incrimination provided by the Fifth Amendment to the United States Constitution." In United States ซ. Pemn, I I I F. Supp. 605 (M.D.N.C. 1953), the court said that the tax did not incriminate because the taxpayer elected to pay, and was not coerced to do so. United States v. Arnold, Jordan and Wingate is not reported. See 345 U.S. at 25 n. 2. 
$[6: 3],{ }^{15}$ the only two Supreme Court decisions on the constitutionality of the Federal "Bookie Tax," however, the Court held that the tax did not incriminate. These decisions rested on the determination that the registration form only required information of future activity, not of prior or present criminal conduct, ${ }^{18}$ Justices Black, Douglas and Frankfurter, dissenting in both cases, ${ }^{17}$ objected to this factual conclusion, ${ }^{18}$ referring to the precise wording of questions six and seven of the registration form ${ }^{19}$ which each -taxpayer must file: "Are you engaged in the business of accepting wagers for your own account?" and, "Do you receive wagers for or on behalf of some other person or persons?"

${ }^{15} 348$ U.S. 419 (1955). The Lewis case involved the prosecution of a District of Columbia resident for not purchasing the fifty dollar stamp. D.C. CoDE $\$ 22-1501$ (1951), prohibits gambling in the district. Petitioner argued that to divulge the information required on the registration form would amount to a coerced confession. $\mathrm{He}$, therefore, claimed Kahriger was not controlling, since there the claim of incrimination was from the state rather than the federal government. The trial court held that the tax was unconstitutional as violative of the fifth amendment. On appeal to the municipal court of appeals, this decision was reversed; and the court, citing the district court cases discussed in note 14 supra, held the law only applied to future activities which are not within the fifth amendment's protection. United States v. Lewis, roo A.2d 40 (Mun. Ct. of App. for D.C. r953).

${ }^{10}$ The majority opinion in Kahriger, written by Mr. Justice Reed, first examined the statute as a tax measure, and then the question of self-incrimination. He stated that it was doubtful whether petitioner could raise the self-incrimination issue, since he had failed to register. In United States v. Sullivan, 274 U.S. 259, 263 (1927), where defendant had refused to file an income tax return claiming it would incrininate him, the Court said, "If the form of return provided called for answers that the defendant was privileged from making he could have raised the objection in the return, but could not on that account refuse to make any return at all." The Court in Kaliriger further held that the fifth amendment was not applicable to future acts wherein an individual had a free choice to violate state or federal laws or not. It should be noted that this opinion only concerned the registration and stamp part of the statute. The Court has never passed on the excise part.

Mr. Justice Minton, who wrote the Lewwis decision, relied entirely on the Kalrriger precedent.

${ }^{17}$ Mr. Justice Jackson reluctantly concurred with the majority in Kaltriger. He said, "I concur in the judgment and opinion of the Court, but with such doubt that if the minority agreed upon an opinion which did not impair legitimate use of the taxing power I probably would join it. . . . This is difficult to regard as a rational or goodfaith revenue measure, despite the deference that is due Congress. On the contrary, it seems to be a plan to tax out of existence the professional gambler whom it has been found impossible to prosecute out of existence. ... It will be a sad day for the revenues if the good will of the people toward their taxing system is frittered away in efforts to accomplish by taxation moral reforms that cannot be accomplished by direct legislation." 345 U.S. at $34-36$.

${ }^{18} 345$ U.S. at 36,$37 ; 348$ U.S. at 42 I.

${ }^{19}$ Special Tax Return and Application for Registry-Wagering Form 11-C, U.S. Treas., Int. Rev. 
These questions are certainly not phrased prospectively; but, instead, it is quite apparent that the majority opinions did not give the words their plain meaning. State prosecutors, however, have not been bound by such a narrow construction; for, with no evidence other than this registration form, they have brought indictments against registrants for violating local gambling statutes. ${ }^{20}$

But even accepting the majority's construction of the questions, a registrant might still be forced to incriminate himself under state and federal conspiracy laws. ${ }^{21}$ In Acklen $v$. State of Tennessee, ${ }^{22}$ for example, the defendant was convicted of conspiracy to violate a state gambling statute solely on the evidence that he had purchased a tax stamp. ${ }^{23}$ On appeal, the conviction was affirmed on the premise that it was reasonable to infer an intent to gamble from the purchase of the stamp. ${ }^{24}$

Furthermore, even assuming that the information elicited by the tax could not directly incriminate the registrant, it could undoubtedly be used to form a cumulative chain of evidence securing his conviction. ${ }^{25}$ State prosecutors are apprised of the registrant's places of illegal activity and also of the names and addresses of everyone who collects wagers

${ }^{20}$ Examples are: Rodriguez v. Culbreath, 66 So.2d 58 (Fla. 1953), and Boynton v. Florida, 75 So.2d $2 \times 1$ (Fla. 1954). The Florida court in both instances held that the state was "foreclosed" from convicting the defendant-gamblers solely on confessions extorted by the tax. Other state courts will probably rule otherwise, since Florida, Michigan and Louisiana are the only three in which self-incrimination is not subject to the dual sovereignty rule. See State v. Kelly, 7 I So.2d 887 (Fla. 1954); Clark v. State, 68 Fla. 433, 67 So. 135 (1914); People v. Den Uyl, 3 8 Mich. 645, 29 N.W.2d 284 (1947); People v. Lay, I93 Mich. I7, 159 N.W. 299 (I916); and Louisiana v. Dominguez, 82 So.2d I2 (La. I955).

${ }^{21} \mathrm{Mr}$. Justice Black, in his Lewis dissent, argued that defendant, by filing the registration form, could be convicted of conspiracy to violate the district's gambling law, which carries a maximum penalty of $\$ 10,000$ and imprisonment for five years. 62 STAT. 70I (I948), I 8 U.S.C. $\$ 37$ I (I952). "If this would not violate the Fifth Amendment's privilege against self-incrimination, it is hard to think of anything that would." 348 U.S. at 425 .

${ }_{23} 267$ S.W.2d I0I (Tenn. I954).

${ }^{23}$ The county district attorney, upon learning the defendant had purchased a wagering stamp, assigned a policeman to "tail" him. The policeman stopped the defendant and asked to see his driver's license. Fumbling in his pocket, he unluckily revealed a tax stamp, which the officer immediately seized. At trial, the state introduced the stamp in evidence, as well as photostatic copies of his application for the stamp.

${ }^{24}$ The court said, "It will not be gainsaid that common sense dictates the conclusion that these parties would not have gone to the trouble and expense complying with this federal law unless they fully intended to engage in the activity of which the tax was levied and paid." Id. at ro4.

${ }^{25}$ See note 13 supra. 
for him. With this information, local officials are in a much better position to enforce state penal sanctions on gambling.

In summary, a realistic appraisal of the true nature of this tax clearly demonstrates that it does force self-incrimination both by coercing a confession of present criminal conduct and of conspiracy to carry on such activity, and by eliciting information which may form a link in a chain of evidence leading to a conviction.

\section{The Protection Offered by the Fifth Amendment}

If, in fact, the Kahriger and Lewis decisions are unrealistic and the gambling tax does compel self-incrimination, the efficacy of the fifth amendment privilege should be assayed by examining the protection which it would offer against the disclosures required by this tax. Two judicial limitations on the self-incrimination clause suggest that even the clear infringement of the clause by these registration requirements would go unchecked.

\section{Dual Sovereignty Rule ${ }^{26}$}

Both the federal and state governments are prohibited by their respective constitutions from coercing testimony which would incriminate under the laws of that particular government. ${ }^{27}$ The "dual sovereignty rule," however, allows the federal government to coerce testimony which would incriminate only under state law, and the state governments to coerce testimony which would incriminate only under federal law..$^{28}$ Similarly, under the rule, the prosecutors of each government may use testimony coerced by the other, even though such testimony could not have been used if coerced by the prosecuting government. This result is rationalized in terms of the political theory that the federal and state governments are two distinct and sovereign entities with separate judicial systems.

${ }^{20}$ The dual sovereignty argument discussed in this section was made to the Court by the government in the Kahriger case. Brief for the United States p. 3.

${ }_{27}$ Forty-six states have constitutional clauses similar to the fifth amendment; and in the two which have no such provision, New Jersey and Iowa, the privilege is incorporated into their common law. Conwin, The Sttpreme Coutr's Construction of the Self-Incrimination Clause, in 2 Selected Essays on Constitutional LaW 1427 (Maggs ed. 1938). For example, PA. Const. art. I, $§ 9$ says, ". . . he cannot be compelled to give evidence against himself." N.C. ConsT. art. I, § 1 I says a person shall ". . . not be compelled to give self-incriminating evidence." CAL. Const. art. I, $\S_{i_{3}}$ says, "No person shall . . . be compelled, in any criminal case, to be a witness against himself."

${ }^{28}$ The overwhelming majority of states have held that fear of incrimination in another state is no defense. See cases collected in Annot., 154 A.L.R. 994 (1945). 
This effect of the interrelationship of federal and state governments on the privilege against self-incrimination was first examined in United States v. Saline Bank of Virginia. ${ }^{29}$ A bill brought in a federal court to authorize examination of defendant's books by federal agents was resisted on the ground that divulgence of the data would expose defendant to criminal prosecution under state law..$^{30}$ In affirming a judgment for defendant, the Supreme Court, through Mr. Chief Justice Marshall, held that the case clearly came within the rule "that a party is not bound to make any discovery which would expose him to penalties." ${ }^{31}$ The Court was not at all disturbed by the fact that defendant feared incrimination under state rather than federal law.

The rule of the Saline case was not repudiated by several subsequent decisions, wherein the defendant was cited for contempt for refusing to answer questions propounded in court. In Brown v. Walker, ${ }^{32}$ the Supreme Court, while upholding a contempt citation in a federal court, ${ }^{33}$ implied that it would have decided differently but for the conclusion that an immunity statute barred state prosecution. ${ }^{34}$ Similarly, in Jack $v$. Kansas, ${ }^{35}$ a state court contempt citation was upheld; ${ }^{36}$ but the decision was rested on the great improbability of federal prosecution. ${ }^{37}$ The

${ }^{20} 26$ U.S. (I Pet.) $100(1828)$.

${ }^{30}$ Defendant was an unincorporated bank, forbidden by the Virginia criminal statutes.

${ }^{31} 26$ U.S. (I Pet.) at ro4. Though the short report of the case makes no mention of whether or not the defendants specifically claimed the self-incrimination privilege, their claim clearly rested on a similar if not identical principle.

${ }^{32}$ I6I U.S. 59 I (I896).

${ }^{33}$ The case involved an investigation of alleged irregularities under the Interstate Commerce Act.

${ }^{34}$ In Coutnselman v. Hitchcock, 142 U.S. 547 (I892), an immunity statute, REV. STAT. $\$ 860$ (I875), was declared unconstitutional, since its coverage was not coextensive with the protection afforded by the fifth amendment. A new immunity statute, 27 STAT. 443 (1893), 49 U.S.C. $\$ 46$ (1946), covering investigations under the Interstate Commerce Commission Act was passed prior to the Brown case. It granted a witness immunity from any prosecution resulting from any transaction about which he could testify. The decision in Brown was five to four. The dissenters thought that no immunity statute, however broad, could be valid, since Congress cannot amend the Constitution, and thus cannot force one to testify by granting immunity.

${ }^{35}$ r 99 U.S. 372 (1905).

${ }^{30}$ Defendant, when questioned before a state grand jury about alleged state antitrust violations, refused to answer, invoking the fifth and fourteenth amendments and claiming that the answers would subject him to federal prosecution.

${ }^{37}$ The Court said that the questions asked by the state could not incriminate defendant in the federal courts, as they pertained only to state and not to federal anti-trust law. The Court noted that Brown \%. Walker, 161 U.S. 591 (1895), was decided on the assumption of the great improbability of prosecution from the other sovereign. 
most forceful disavowal of the dual-sovereignty rule then appeared in Ballman v. Fagin, ${ }^{38}$ where a federal contempt conviction was before the court. ${ }^{39} \mathrm{Mr}$. Justice Holmes, for the majority, expressly rejected the rule, and held that a refusal to testify in a federal court was clearly justified by the fear of subsequent state prosecution. ${ }^{40}$

Notwithstanding such precedent, the dual sovereignty rule gained a foothold in Hale v. Henkel, ${ }^{41}$ where defendant was cited for contempt by a federal district court for refusing to furnish certain corporate records to a grand jury. Defendant contended, inter alia, that a certain immunity statute ${ }^{42}$ which would bar any federal prosecution based on these records, would not offer similar protection against a state prosecution..$^{43}$ The Supreme Court upheld the contempt citation, and, in a statement which might have been dictum, ${ }^{44}$ ignoring Ballman v. Fagin, ${ }^{45}$ relied heavily on doubtful English precedent, ${ }^{40}$ and gave its first expression to

${ }^{38} 200$ U.S. 186 (1906).

${ }^{30}$ Defendant had refused to answer questions in a federal grand jury proceeding, claiming they would incriminate him under state laws. In fact, criminal prosecutions against defendant were pending at this time in the Ohio courts.

"O Significantly, Mr. Justice Holmes cited United States v. Saline Bank of Virginia, 26 U.S. ( 1 Pet.) Ioo ( 1828 ), in his reversal of the lower court.

31201 U.S. 43 (1906).

32 STAT. 904 (I903), r 5 U.S.C. $\S_{32}$ (1946). For additional litigation concerning this anti-trust immunity statute, see United States v. Monin, 317 U.S. 424 (1943).

${ }^{43}$ The government attorneys agreed that defendant could not be forced to furnish the records if the immunity statute did not prevent state prosecution. Grant, op. cit. supra note 2, at 194.

"Since defendant was claiming the self-incrimination privilege for corporate records, the actual decision of the Court rested on the rule that a corporation and its records are not protected by the self-incrimination clause, as it is merely a personal privilege. See Wilson v. United States, 221 U.S. 361 (IgII). Therefore, the additional statements by the Court were not necessary for its decision. But three months after the Hale case, this immunity statute was specifically amended to restrict its application to natural persons. 34 STAT. 798 (1906), 15 U.S.C. \$ 33 (1946).

${ }^{45}$ Both cases were decided during the same Court term.

${ }^{40}$ As authority for this dual sovereignty rule, the Court cited King of Two Sicilies ข. Willcox, I Sim. (N.S.) 301, 6I Eng. Rep. I16 (Ch. 1851), as the leading English case on this question. In that case, defendant was being sued in England; and he refused to answer questions in court, fearing incrimination in Sicily. The English court ordered defendant to answer, since he had not shown that any prosecution was inminent, and since the court was not bound to know the criminal laws of a foreign country. The dual sovereignty rule could not rest on the same rationale in the United States, as the federal courts will take judicial notice of the criminal laws of the various states. MCCORMICK, EVIDENCE 695 (1954). In addition, the Supreme Court in the Henkel case completely ignored the subsequent English case of United States of Anterica $v$. McRae, L.R. 3 Ch.App. 79, 85 ( 1867 ), which clearly rejected the dual sovereignty rule. This represents the present English position. See Grant, op. cit. supra note 2, 
the rule of dual sovereignty: even if the immunity statute applied only to the federal government the defendant would, nevertheless, be required to answer.

These remarks in the Henkel case, themselves indecisive of the problem there, ${ }^{47}$ apparently led the Court to cite that case in the first decision to establish the dual sovereignty rule as a principle of constitutional law. In United States v. Murdock, ${ }^{48}$ the Supreme Court unequivocally endorsed the rule by holding that fear of state prosecution was no legitimate basis for a refusal to answer questions in a federal court. ${ }^{40}$ Twelve years later, in Feldman v. United States, ${ }^{50}$ the Court,

at 61-62. In the McRae case the United States was suing a former Confederate agent in England. Defendant refused to answer certain questions, pointing to an American statute which would forfeit his property under certain circumstances. The court held that he could not be forced to answer such questions, since the possibility of incrimination in another jurisdiction was clearly shown.

17 Though the Supreme Court did not consider this dual sovereignty problem again until twenty-five years after Henkel, a significant decision appeared in the district court of Washington. United States v. Lombardo, 228 Fed. 980 (W.D. Wash. 1915). Defendant had refused to comply with the registration requirements of the Federal White Slave Act, 36 STAT, 826 (1910), I 8 U.S.C. $\$ 402$ (2) (1946), which required everyone who harbored an alien prostitute to register with the Commissioner of Immigration. Defendant argued that the registration form would incriminate her under state laws. The court ignored the two sovereignties rationale, and declared the statute unconstitutional hecause of the danger of state prosecution. On appeal, the Supreme Court sidestepped the issue by stating that the district court had no jurisdiction to hear the question, since the action should, instead, have been brought in the district court for the District of Columbia. United States v. Lombardo, 24 I U.S. 73 (I9I6).

Similarly, during the same twenty-five year period, other federal trial courts allowed the privilege where there was danger of state incrimination. See In re Doyle, 42 F.2d 686 (S.D.N.Y. 1930); In re Gasteiger, 290 Fed. 4 Io (E.D.N.Y. x 923); Buckeye Powder Co. v. Hazard Powder Co., 205 Fed. 827 (D. Conn. I9I3).

${ }^{48} 284$ U.S. I4I (193I).

${ }^{40}$ This was an appeal from a dismissal by a district court of a contempt citation, resulting from defendant's refusal to disclose information about his income tax return on the ground that it would subject him to state prosecution. Though the Court, in reversing, held defendant had waived the self-incrimination privilege, they firmly announced the dual sovereignty rule. For authority, the Court cited King of Two Sicilies v. Willcox, I Sim. (N.S.) 301, 6I Eng. Rep. I 16 (Ch. 185I), for the English rule from which the self-incrimination clause got its meaning. Also cited were the prior Supreme Court cases of Counselman v. Hitchcock, I42 U.S. 547 (I 892 ); Brown v. Walker, I6I U.S. 59 I (I896); Jack v. Kansas, I99 U.S. 372 (I905); and Hale v. Henkel, 201 U.S. 43 (Ig06). A constitutional rule of law thus developed from an English rule the Court got backwards, from the Counselman case, where nothing was said of state prosecution, and from the Brown and Jack cases, which were based on the improbability of any prosecution from the other sovereign. Hale v. Henkel had also relied on the erroneous English rule. Though the Court cited these cases as if dual sovereignty were a settled rule, two years later, after defendant had been convicted of tax fraud, and the case was 
[4:3], ${ }^{51}$ confirmed the Murdock decision by ruling that testimony coerced by a state court was properly admitted in a federal prosecution..$^{52}$ Neither opinion attempted to reconcile its result with the blunt rejection of dual sovereignty in the Saline Bank and Fagin cases.

This tortuous line of precedent from the Saline Bank case to the Court's most recent pronouncement in the Feldman case has resulted in conflicting decisions in the lower federal ${ }^{63}$ and state ${ }^{54}$ courts. The most

again appealed to the Court, they said, "Not until this court pronounced judgment in United States $v$. Murdock . . . had it been definitely settled that one under examination in a federal tribunal could not refuse to answer on account of probable incrimination under state law." United States v. Murdọck, 290 U.S. 389, 396 (1933).

${ }^{50} 322$ U.S. 487 (1943).

${ }^{52}$ Messrs. Justices Jackson and Murphy did not participate in this case. Had they done so, it is entirely possible the decision would have been five to four the other way. By comparing the language of Mr. Justice Murphy in United States v. White, 322 U.S. $694,698-99$ ( 1944$)$, and the dissents of both of them in Shapiro v. United States, 335 U.S. I, 70-7I (1948), it seems likely they would have lined up with the minority In such event, the dual sovereignty rule might well have disappeared.

${ }^{62} \mathrm{Mr}$. Justice Black dissented. "As the decisions reflect, the previously declared attitude of the Court toward this prohibition [the self-incrimination privilege] has been that it 'must have a broad construction in favor of the right it was intended to secure.' ... Testimony is no less compelled because a state rather than a federal officer compels it. . . . The great principles of liberty written in the Bill of Rights cannot safely be treated as imprisoned in walls of formal logic built upon vague abstractions found in the United States Reports. ... A And history supports no argument that the framers of the Fifth Amendment were interested only in forbidding the extraction of an accused's testimony as distinguished from the use of his extracted testimony. . . . By broadly outlawing the practice of compelling such testimony the Fifth Amendment struck at this evil at its source, seeking to eliminate the possibility that compelled testimony would ever be available for use to punish a defendant." 322 U.S. at 496-500.

${ }^{53}$ In United States v. Di Carlo, ro2 F. Supp. 597 (N.D. Ohio I952), the district court for northern Ohio rendered a decision diametrically at variance with the Murdock and Feldman cases. As part of a Kefauver investigation, defendant was questioned in an open hearing about his bookmaking operations. He refused to answer, invoking the fifth amendment, since state officials were present. The claim was based, therefore, on the fear of state, and not federal, incrimination. In the contempt proceeding before the district court, defendant's refusal was upheld. The court, citiug United States $v$. Saline Bank of Virginia, 26 U.S. (I Pet.) Ioo (1828), and Ballman v. Fagin, 200 U.S. I 86 (1906), said the fifth amendment's protection extends to questions designed to reveal state violations, and that the amendment operates as a restraint on federal officers investigating state crimes. No appeal was taken by the government.

${ }_{54}$ In Boynton ข. Florida, 75 So.2d 2 I 1215 (Fla. I954), (see note 20 supra), the state supreme court, speaking of dual sovereignty, said, "This question is complicated by the fact that the Federal cases cited herein give us no dependable guide for determination of the question. Some of them indicate that in the Federal Court one cannot plead self-incrimination on the ground that his testimony may be used to incriminate him in the State Court, while others convey the opposite impression."

In the recent case of Louisiana v. Dominguez $[4: 3], 82$ So.2d 12 (La. 1955), the 
significant objection to the dual sovereignty rule, however, is not its anomalous development, but rather its present operation. ${ }^{55}$ The rule, as it applies today, imposes a pernicious limitation on the fifth amendment guarantee and reflects a perhaps unfortunate judicial antipathy to the privilege against self-incrimination.

\section{“Fundamental Right" Rule}

In contrast to the first amendment, the fifth is not restricted ex $v i$ termini to Congress or the federal government. Instead, it broadly states that no one shall be compelled to be a witness against himself. The Supreme Court in Barron v. Baltimore, ${ }^{56}$ however, drastically inhibited the effect of this literal language by holding that all of the first eight amendments applied only to action by the federal government. ${ }^{57}$

question raised was whether the state could coerce a confession of gambling which might then be used by the federal government to convict the defendant of evading the tax. Defendant had refused to answer the questions propounded. The lower court cited him for contempt, since he had been granted immunity from state prosecution. But the supreme court reversed, holding that the defendant did have the protection of the fifth amendment in a state court as to questions that could convict him in a pending federal suit. Unfortunately, the majority opinion does not admit that they are following the minority view in our country. They cited People v. Den Uyl, 318 Mich. 645, 29 N.W.2d 284 (1947), and State v. Kelly, 71 So.2d 887 (Fla. 1954), as though they represent the settled American view (see note 20 supra.). In discussing the dual sovereignty rule, the majority quotes from the Den $U_{y l}$ case: "It seems like a travesty on verity to say that one is not subjected to self-incrimination when compelled to give testimony in a State judicial proceeding which testimony may forthwith be used against him in a Federal criminal prosecution." 82 So.2d at I8. The dissenters cited Feldman v. United States, 322 U.S. 487 (I943); United States v. Murdock, 284 U.S. I4I (193I); and Twining v. New Jersey, 2 II U.S. 78 ( 1908 ), to support their view that the fifth amendment offered defendant no protection in this suit.

${ }^{E 5}$ See Mr. Justice Black's dissent in Irvine v. California, 347 U.S. I28 (I954), wherein he again claimed that this gambling tax violated the self-incrimination clause. Writing of dual sovereignty, he said, "I cannot agree that the Amendment's guarantee against self-incriminating testimony can be spirited away by the ingenious contrivance of using federally extorted confessions to convict of state crimes and vice versa. . . . This treatment of the states and the Federal Government as though they were entirely foreign to each other is wholly conceptualistic and cannot justify such a narrow interpretation of the Fifth Amendment's language and the resulting frustration of its purpose." Id. at 140 .

${ }_{30}$ U.S. ( 7 Pet.) 243 ( 1833 ).

${ }^{67}$ The question presented by the case was whether or not that part of the fifth amendment which prevents the taking of private property for public use without just compensation applied to individual state action. The Court, in holding it did not, went further and said, "These amendments contain no expression indicating an intention to apply them to the state governments. This court cannot so apply them." Id. at 250 . No other reason was given as the basis for this broad holding. It should be noted that the Court, with the exception of the first amendment, could easily have decided con- 
The adoption of the fourteenth amendment in I 868 afforded the Supreme Court an opportunity to re-examine this position; and subsequently there evolved the doctrine that the due process clause in the fourteenth amendment "made applicable to the states" all those guarantees in the Bill of Rights which were deemed "fundamental."

Any intelligent appraisal of this doctrine, as it bears on the present inquiry, must begin with the observation that only two guarantees ${ }^{50}$ in the Bill of Rights lend themselves to emasculation by the dual sovereignty theory. All of the other clauses would realize their fullest extent of protection by restraining the action of each political unit within its own sphere of activity. ${ }^{60}$ The result of this phenomenon is that, for the most part, protection is extended to the ultimate limits when a guarantee is made "applicable to the states." In the case of the self-incrimination privilege, however, it might be argued that to make it "applicable to the states" would have no greater effect than to prohibit the state courts from using testimony coerced by state officials. ${ }^{61}$

It is apparent, though, that the Supreme Court did not contemplate such linguistic niceties when it announced that the due process clause made all "fundamental" rights "applicable to the states." Rather, it seems that, in the case of every amendment except the first, the Court is overruling Barron $v$. Baltimore and reading the language of the amendment according to its literal import. If this is actually the judicial process, then a determination that the self-incrimination privilege is "fundamental" ${ }^{22}$ would mean that a broad and unitary command should

versely by writing, "These amendments contain no expression indicating an intention $110 t$ to apply them to the state governments. This court cannot so restrict them.' Such an interpretation would be more in conformity with the liberal construction afforded the Bill of Rights. See Boyd v. United States, I16 U.S. 616, 635 (1886), "[C] onstitutional provisions for the security of person and property should be liberally construed."

${ }^{58} \mathrm{Mr}$. Justice Brandeis, in his concurring opinion in Whitney v. Califortia, 274 U.S. 357,373 (1927), says, "[I]t is settled that the due process clause [of the fourteenth amendment] applies to matters of substantive law as well as to matters of procedure. Thus all fundamental rights comprised within the term liberty, are protected by the Federal Constitution from invasion by the States." See also Palko v. Connecticut, 302 U.S. 319,325 (1937).

${ }^{50}$ The search and seizure provision of the fourth amendment and the self-incrimination privilege of the fifth.

${ }^{80}$ For example, if the third or eighth amendments were applicable to the states, neither a quartering of troops in homes nor excessive bail could be required by cither jurisdiction.

${ }^{81}$ Such an interpretation would effect no change in the present law, since every state grants protection from self-incrimination. See note 27 supra.

${ }^{82} \mathrm{Mr}$. Justice Black, dissenting in Irvine v. California, 347 U.S. 128 , 141-42 
apply to all the United States, prohibiting the coercion of testimony without regard to where it would incriminate, and likewise prohibiting the use of coerced testimony no matter where it had been coerced.

The Supreme Court in Twining v. New Jersey ${ }^{63}$ held that the privilege against self-incrimination was not a "fundamental" right. ${ }^{64}$ Though the effect of this decision is apparently still controlling, its soundness as an original proposition is open to question.

In determining which of the guarantees in the Bill of Rights are "fundamental," the Supreme Court has consistently looked to their historical development in England and in the colonies up to the time of the Constitutional Convention. ${ }^{65}$ Though legal historians are in mild dispute as to the earliest roots of the self-incrimination privilege, ${ }^{66}$ there is general agreement that it emerged in the fifteenth century, ${ }^{67}$ and that by the time of the colonization of America, it was universally recognized in England as a basic liberty ${ }^{68}$ In conformity with this historical tradition, the privilege was accorded to everyone throughout the colonies in the eighteenth century, ${ }^{69}$ and many of them incorporated specific provisions for it into their "constitutions." James Madison recognized the

(1954), said, ". . . I think the Fourteenth Amendment makes the Fifth Amendment applicable to states and that state courts like federal courts are therefore barred from convicting a person for crime on testimony which either state or federal officials have compelled him to give against himself."

${ }_{63}{ }_{21}$ U U.S. 78 (1908).

04 The question presented by the case was whether a state trial court judge, pursuant to a state statute, could, consistent with the fourtenth amendment, instruct a jury that an unfavorable inference could be drawn from an accused's failure to take the stand in his own behalf. The Court held that the state law violated no constitutional right. Though unnecessary for the decision, the Court added that the self-incrimination privilege was not part of the "law of the land" prior to the separation of the colonies from England and, thus, not made applicable to the states by the fourteenth amendment.

${ }^{05}$ See Near v. Minnesota, 283 U.S. 697, 708, 713 (1931); Thornhill v. Alabama, 3 ro U.S. 88 (1940); and Truax v. Corrigan, 257 U.S. 3 12 (1921).

${ }^{\circ 0}$ See the historical discussion in MORGAN AND MAGUIRE, EvidENCE 4ro-I7 (195 $\mathrm{x}$ ). For other historical studies, see McCormick, Evidence 252-57 (1954); Pittman, The Colonial and Constitutional History of the Privilege against Self-Incrimination in America, 2 I VA. L. Rev. 763 (1935); Riesenfeld, Law-Making and Legislative Precedent in American Legal History, 33 MinN. L. REV. 103, II5-20 (1949); Corwin, The Supreme Court's Construction of the Self-Incrimination Clause, in 2 SELECTED ESSAYS ON CONSTITUTIONAL LAW I400-09 (Maggs ed. I938).

${ }^{07}$ Corwin, id. at x 402.

${ }^{\circ 8} I d$. at 1406 .

${ }^{60}$ Griswold, The Fifth Amendment Today 4. (1955).

${ }^{70}$ Section 8 of the Virginia Declaration of Rights of 1776 said, "nor can he be compelled to give evidence against himself." North Carolina's and Pennsylvania's declarations irr the the same year used similar words. Massachusetts and New Hamp- 
importance of such protection ${ }^{71}$ and wrote the self-incrimination clause into the fifth amendment in unrestricted terms. Therefore, both the reasonable import of this clause and its historical background indicate that freedom from self-incrimination should be denominated a "fundamental" requirement of common liberty and justice.

This conclusion is buttressed by recent Supreme Court decisions holding that the first amendment guarantee of separation of church and state is "fundamental" and, therefore, made applicable to the states by the fourteenth. ${ }^{72}$ With the long history of an established church in England and in many of the colonies, ${ }^{73}$ it would be anomalous to hold church-state freedom of the first amendment a "fundamental" right and at the same time to hold the self-incrimination clause of the fifth not "fundamental."

\section{Conclusion}

In the inevitable attrition between community interests and individual liberties on a constitutional level, the wear seems always to be the more telling on the latter. Our fifth amendment privilege against self-incrimination was conceived by a realization of this danger and born of the hope that a fundamental personal right could be insulated against the friction of group pressure.

It should be apparent from the foregoing discussion that the clause has, in one significant area, failed of this intended purpose. Perhaps a contributing factor is that a contemporaneous conflict between federal and state "police powers" confounds the issues in that area. ${ }^{74} \mathrm{~A}$ more

shire also had similar provisions passed before the fifth amendment was ratified in 1791 . Corwin, op. cit. supra note 66, at 1399-1400.

${ }^{71}$ GRIswold, op. cit. supra note 69 , at 35 .

72 Zorach v. Clauson, 343 U.S. 306 (1952); McCollum v. Board of Education, 333 U.S. 203 (1948), and Everson v. Board of Education, 330 U.S. I (1947). See Note, 4 DUKE B.J. 127, n. I (1954).

${ }^{73}$ In contrast to our present constitutional doctrine, England still has an established church. Pfeffer, Church, State and Freedom 45-47 (1953). Even after ratification of the first amendment, four states, Massachusetts, Connecticut, New Hampshire and Maryland had established churches with tax aid. Massachusetts did not completely disestablish until $\times 8_{33}$, forty-two years after the adoption of the first amendment. Id. at 126 .

74 The courts have dealt with the argument that this $\operatorname{tax}$ is an unconstitutional usurpation of state police power almost as much as with the self-incrimination argument. See cases cited in note 14 supra. Perhaps the courts are inclined to sustain the tax against the argument that it is an invalid police measure because of a realization that the states are unable to deal with the nationwide problems of gambling. See note 12 supra. If so, then it is suggested that these problems should be met with by an increase in the 
likely explanation, however, is that current political philosophy accords so much weight to the public interest involved that a broad constitutional protection of the correlative private right is no longer justifiable.

If so, it is suggested that the self-incrimination privilege should be abrogated by constitutional amendment rather than by judicial circumvention. Whatever may be any particular individual's evaluation of the fifth amendment privilege, it is certainly disturbing that a constitutional guarantee can be so easily undermined.

Duncan O. McKeE

authority of such federal administrative bodies as the Interstate Commerce Commission and the Federal Communications Commission. This would be the more desirable course of action, not only because it would not trespass on constitutional civil rights, but also because it would not be an effort "to accomplish by taxation moral reforms that cannot be accomplished by direct legislation." See opinion of Mr. Justice Jackson, quoted in note I 7 supra. 